\title{
Design of Organic Rankine Cycle (ORC) Power Plant Systems by Using Flat-Plate Solar Collector
}

\author{
Sutopo Purwono Fitri ${ }^{1}$, Muhammad Badrus Zaman ${ }^{2}$, Fahri Adib Azizi ${ }^{3}$ \\ (Received: 07 August 2019 / Revised: 09 September 2019 / Accepted: 30 September 2019)
}

\begin{abstract}
In rural areas that do not have electricity still exists in Indonesia. In this study, it can be used as an alternative power plant that can be used by the countryside. The system used in this study is the new types of power plants, namely the Organic Rankine Cycle (ORC) system. In connection with the problems stated above, through this research, an effort will be made to design an ORC power generation system. The ORC power plant system that will be designed utilizes solar energy sources and working fluids. Solar power is used to heat the heating fluid in the form of water. This heating water is used to vaporize the working fluid which can evaporate at low temperatures and high pressures. So that the working fluid gas can be used to rotate the turbine shaft and produce electrical energy through a generator. Simulation is done using energy system software. In addition to simulations, examples of manual calculations are also needed for validation. The simulation results of the ORC generating system design on the two working fluids produce the greatest power at the pump outlet pressure of 6 bar with Wnet of 13.61 $\mathrm{kW}$ and the smallest power is generated by the pump outlet pressure of $5.03 \mathrm{~kW}$. While the design simulation of the ORC generating system produces power close to $10 \mathrm{~kW}$ at the pump outlet pressure of 5 bars with $11.38 \mathrm{~kW}$. The flat collector solar-plate system gets the energy that is useful for collectors of $191.92 \mathrm{~W}$ and an efficiency of $9.8 \%$.
\end{abstract}

Keywords — design, flat-plate collector, ORC, power plants, system, working fluids.

\section{INTRODUCTION}

$\mathrm{E}_{\mathrm{l}}$ ectric energy is one of the most widely used energy today. Technology and science that continues to evolve have encouraged the use of energy in all aspects of human life, both for industrial and household needs. At present, there is still a rural area that does not have electricity resources in the territory of Indonesia. In this study, it can be used as an alternative power source that can be used by rural areas. The generating system to be examined is one of the new types of power plants, namely the Organic Rankine Cycle system. Renewable energy sources are power plants in the future.

Solar thermal energy is one of the renewable energy sources that is widely used in small scale applications and promises to be carried out on a large scale of research and development. Meanwhile, from a simple equipment system and the magnitude of the benefits to be obtained, then with the technological advances that exist today, solar systems can be made. Solar power plants both directly and indirectly can work by changing solar radiation into electricity. Among the positive benefits of this solar power plant are free from environmental pollution. Judging from its geographical condition, Indonesia has a daily average of solar radiation of 14,389 $\mathrm{kWh} / \mathrm{m}^{2}$, which accumulatively if all the potential in Indonesia is utilized will reach 1,036 x 109 MW taking into account Indonesia's land area of 2 million $\mathrm{km}^{2}$. In this study, we will make a case study of an alternative power

Sutopo Purwono Fitri, Departement of Marine Engineering, Institut Teknologi Sepuluh Nopember, Surabaya, 60111, Indonesia. E-mail : spurwonof@yahoo.com

Muhammad Badrus Zaman, Departement of Marine Engineering, Institut Teknologi Sepuluh Nopember, Surabaya, 60111, Indonesia. Email : druz_zaman@ne.its.ac.id generation system that is used as a source of electrical energy in the countryside, which consists of several houses that require $10 \mathrm{KW}$ of power.

\section{METHOD}

A. Organic Rankine Cycle (ORC)

The organic Rankine cycle is a thermodynamic cycle that uses mass fluid or organic chemicals where changes in phase (liquid-vapor) or boiling point (boiling point) occur at low temperatures from ordinary (liquid-vapor) phase changes. In the fluid, the utilization of heat follows the Rankine cycle from low-temperature sources such as solar panels, biomass and so on, which then low temperature heat is converted into useful work, which is then converted into electricity.

The working principle of the ORC is the same as the working principle in the Rankine cycle, where the working fluid is pumped into a boiler (heat exchanger) then the liquid is evaporated and passed through the turbine and then condensed in the ideal cycle, the expansion step is isentropic, and the evaporation and condensation process is isobaric. [2]

B. Pentafluoropropane (R234FA)

1,1,1,3,3-Pentafluoropropane (HFC-245fa) is a hydrofluorocarbon produced by Honeywell and in Asia by Sinochem. Honeywell markets the HFC-245fa under the Enovate and Genetron $245 \mathrm{fa}$ brands. HFC-245fa is also known as pentafluoropropane and with its chemical name 1,1,1,3,3, -pentafluoropropane. Unlike CFCs and HCFCs, these substances have no ozone depletion potential and are

Fahri Adib Azizi, Departement of Marine Engineering, Institut Teknologi Sepuluh Nopember, Surabaya, 60111, Indonesia. E-mail : fahri.adib96@gmail.com 
almost non-toxic. Honeywell calls this as. R245FA is the main working fluid commonly used in Organic Rankine Cycle (ORC) generating systems. [3]

TABLE 1.

R245FA PHYSICAL PROPERTIES

\begin{tabular}{ccc}
\hline Characteristic & Value & Unit \\
\hline Chemical name & Pentafluoropropane & - \\
Molecular mass & 134.05 & $\mathrm{~g} / \mathrm{mol}$ \\
Boiling point (at 1 atm) & 15.03 & ${ }^{\circ} \mathrm{C}$ \\
Critical temperature & 154.01 & ${ }^{\circ} \mathrm{C}$ \\
Critical pressure & 36.51 & $\mathrm{kPa}$ \\
Critical density & 1338.54 & $\mathrm{~kg} / \mathrm{m}^{3}$ \\
\hline
\end{tabular}

\section{Solar System}

The relationship between earth and sun has a distance called eccentric distance that has a variation of $1.7 \%$. From the results of astronomical measurements, the average distance between the earth and the sun is $1,495 \mathrm{x}$ $1011 \mathrm{~m}$ with a tendency of sun $32^{\circ}$ has a solar constant (GSC) of $1367 \mathrm{~W} / \mathrm{m} 2$. The intensity of solar radiation outside the Earth's atmosphere depends on the distance between the sun and the earth. Each year, this distance varies between $1.47 \times 108 \mathrm{~km}$ and $1.52 \times 108 \mathrm{~km}$ and the result is that the E0 emission increases up between 1325 $\mathrm{W} / \mathrm{m} 2$ to $1412 \mathrm{~W} / \mathrm{m} 2$. The average value is called the solar constant with the value E0 $=1367 \mathrm{~W} / \mathrm{m} 2$. This emission cannot reach the surface of the earth. In good weather during the day, the emission can reach $1000 \mathrm{~W} /$ $\mathrm{m} 2$ on the surface of the earth. The greatest insolation occurs on part of cloudy and sunny days. Because of the sun's rays bouncing through the clouds, insolation can reach up to $1400 \mathrm{~W} / \mathrm{m} 2$ for the short term. [4]

\section{Flat-Plate Collectors}

Flat Plate Solar Collector is a medium that used to heat the working fluid that flows by converting solar radiation energy into heat. The heated fluid in the form of oil, oil, and air flat plate solar collector has an output temperature below $95^{\circ} \mathrm{C}$. in its application flat plate collectors are used to heat air and water (Goswami, 1999). [5]

flat plate solar collector which contains information on the collector, there is an entry temperature and working fluid exit temperature, collector coated with transparent black glass, working fluid flow in the pipe, and absorption of solar radiation intensity. Flat plate solar collector is a longitudinal solar collector that coated with transparent black glass with a certain slope to capture solar radiation energy. The process of use is easier and simpler compared to prismatic solar collectors. The components of a flat plate solar collector consist of "black" surfaces as absorbers of solar radiation energy that transferred to the fluid. The translucent cover (glass) serves to reduce the effects of radiation and convection that are lost to the atmosphere. [5]

The fluid flow pipes function to drain the fluid to heated and insulation to reduce the loss of conduction to the environment. The flat plate solar collector scheme is shown in the figure. Collector performance expressed by energy balance, which describes the distribution of solar energy that comes to useful energy, and some of the energy lost (Philip Kristanto, 2001). [5]

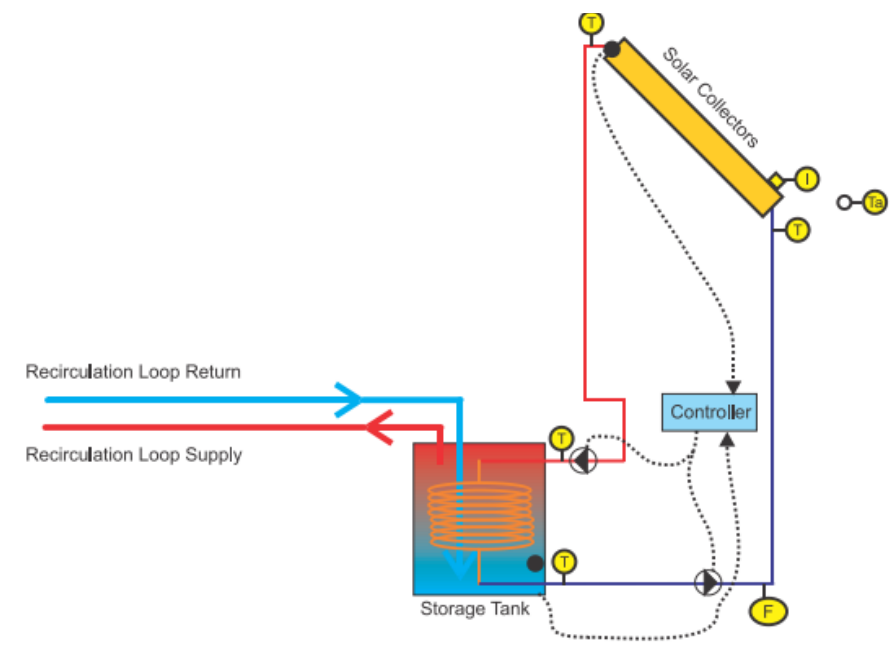

Figure. 1. Flat Plate Solar Collector Cycle

This type designed for applications that require heat energy at temperatures below $100^{\circ} \mathrm{C}$. This type of specification can see from the absorber in the form of a flat plate made of a material with high thermal conductivity and coated with black paint. Flat plate collectors utilize direct and scattered (beam and diffuse) solar radiation, do not need a solar tracker, and only require a small amount. [5] 
This type designed for applications that require heat energy at temperatures below $100^{\circ} \mathrm{C}$. This type of specification can see from the absorber in the form of a flat plate made of a material with high thermal conductivity and coated with black paint. Flat plate collectors utilize direct and scattered (beam and diffuse) solar radiation, do not need a solar tracker, and require little maintenance. Common applications of this type of collector used for water heaters, building heaters, air conditioning, and industrial heat processes. Supporting components found in flat plate collectors include; transparent cover, absorber, insulation, and framework. [5]

The collector's performance measurement is the efficiency of the collection (collection efficiency), which is defined as the ratio of the addition of useful energy $(\mathrm{Qu})$ over a certain period to the solar energy that befalls it during the same time. For actual efficiency, $\eta_{a}$, can be calculated by the equation:

$$
\eta_{a}=\frac{Q_{u, a}}{A_{C} \cdot I_{T}}
$$

For the calculation of actual efficiency based on actual useful energy, it can be calculated using the equation approach:

Where:

$$
Q_{u, a}=\dot{\mathrm{m}} \cdot C_{p}\left(T_{o}-T_{i}\right)
$$

$Q_{u, a}=$ The useful energy of the collector is actually each unit area $(\mathrm{W} / \mathrm{m} 2)$

$\dot{\mathrm{m}}=$ Fluid mass flow rate $(\mathrm{Kg} / \mathrm{s})$
$C_{p}=$ Fluid type heat $(\mathrm{J} / \mathrm{Kg} \cdot \mathrm{K})$, the value of $C_{p}$ obtained from fluid properties based on temperature $T_{\text {film }}=\frac{T_{o}+T_{i}}{2}$

$I_{T} \quad=$ The intensity of solar radiation that befalls the collector $(\mathrm{W} / \mathrm{m} 2)$

$T_{i} \quad=$ Incoming fluid temperature (K).

$T_{o} \quad$ = Outgoing fluid temperature (K).

\section{E. Ideal Rankine Cycle}

The ideal cycle that underlies the work cycle of a steam power plant is the Rankine cycle. The Rankine cycle is different from the air cycles in terms of the working fluid, which undergoes a phase change during the cycle during evaporation and condensation. Another difference in the thermodynamics of the steam cycle compared to the gas cycle is that the heat transfer in the steam cycle can occur isothermally. The process of heat transfer, which is the same as the heat transfer process in the Carnot cycle, can be achieved in the wet steam area where the enthalpy changes in the working fluid will produce evaporation or condensation, but not at changes in temperature. Temperature only regulated by fluid vapor pressure. [6]

Pump work in the Rankine cycle to increase the working fluid pressure in the liquid phase will be much smaller than the compression for the steam mixture under the same pressure in the Carnot cycle. The ideal Rankine cycle can be illustrated in the T-S diagram as shown below. [6]

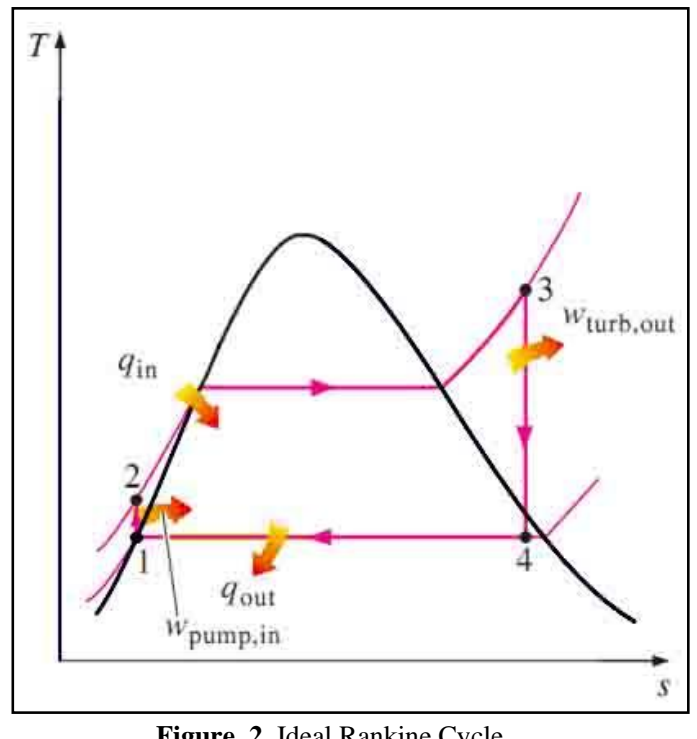

The ideal Rankine cycle consists of 4 stages:

1 - 2 Isentropic compression with a pump

2 - 3 Heat additions in the boiler are isobaric

3 - 4 Isentropic expansion in turbines

4-1 heat release on the condenser isobaric and isothermal)

Water enters the pump under condition 1 as saturated liquid and is compressed to boiler operating pressure. Water temperature will increase during isentropic compression due to a decrease in the specific volume of water. Water enters the boiler as a compressed liquid in condition 2 and will become superheated steam under condition 3 . Where heat is given by the boiler to water at a constant pressure. The boiler and all the parts that produce steam are referred to as steam generators. Superheated vapor at condition 3 will then enter the turbine to be expanded isentropically and will produce work to rotate the shaft connected to the electric generator so that electricity can be generated. The pressure and assuming there is no heat transfer around it, the equilibrium of the mass and energy rates is [6]

$$
(q-w)=\left(h_{1}-h_{2}\right)+\left(\frac{v_{1}^{2}-v_{2}^{2}}{2}\right)+g\left(z_{1}-z_{2}\right)
$$

the temperature of the steam will drop during this process to state 4 where steam will enter the condenser 
and usually it is in the form of saturated steam. This steam will be liquefied at a constant pressure inside the condenser and will leave the condenser as the saturated liquid that will enter the pump to complete this cycle. [6]

1. Pump

The liquid condensate leaving the condenser in condition 1 is pumped from the condenser into the boiler so that the pressure rises. By using the volume set around the pump and assuming there is no heat transfer around it, the density of the mass and energy rates is

$$
(q-w)=\left(h_{1}-h_{2}\right)+\left(\frac{v_{1}^{2}-v_{2}^{2}}{2}\right)+g\left(z_{1}-z_{2}\right)
$$

or

$$
w_{p}=h_{2}-h_{1}
$$

Where $\boldsymbol{w}_{\boldsymbol{p}}$ is the incoming power per unit of mass through the pump.

2. Boiler

The working fluid leaves the pump in condition 2 which is called water-filling, heated to saturation and evaporated in the boiler. By using a set volume that covers the boiler tube and drum which flows water-filling and condition 2 to condition 3 , the equilibrium of the mass and energy yields.

$$
Q_{\text {in }}=h_{3}-h_{2}
$$

\section{RESULT AND DISCUSSION}

The system modeling that will be designed is a closed cycle ORC generating system. The components used include the evaporator, turbine, generator,
Where Qin is the rate of heat transfer from the energy source into the working fluid per unit mass through the boiler.

3. Turbine

Steam from the boiler in condition 3 , which is at a temperature and pressure that has been raised, expands through a turbine to produce work and then is discharged into the condenser in condition 4 with relatively low pressure. By ignoring the heat transfer with its surroundings, the equilibrium of the energy and mass rates for the volume set in a turbine in the soft condition becomes

$$
w_{t}=h_{3}-h_{4}
$$

Where $\dot{m}$ expresses the rate of mass flow from the working fluid, and wt is the rate of work produced per unit of mass vapor through a turbine.

4. Condenser

In the condenser heat transfer occurs from the vapor to cooling water flowing in a separate flow. The condensed steam and the temperature of the cooling water increase. In steady-state, the equilibrium of the mass and energy rates for the regulating volume surrounding the condensation and heat exchanger parts is

$$
Q_{\text {out }}=h_{4}-h_{1}
$$

condenser, working the fluid pump, solar collector water pump. In the initial system modeling, the Aspen Plus v10 software was used with the reason that the software can show clearer schematic system images. Figure 3. show a schematic diagram of an ORC in general.

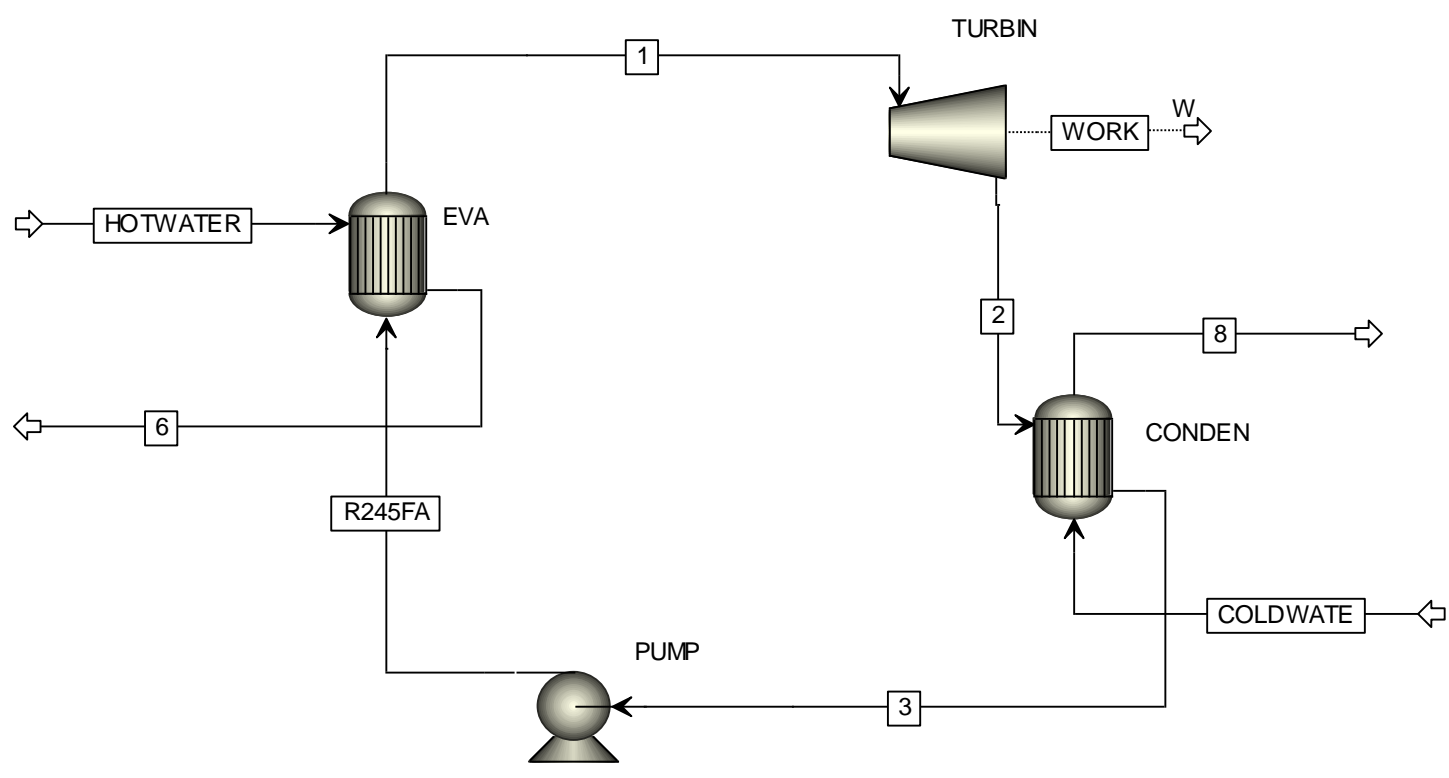

Figure. 3. Organic Rankine Cycle Schematic Diagram

In figure 3. Shows a simple schematic ORC (Organic Rankine Cycle) diagram using a heat source from a flat plate solar collector before the evaporator. This flat plate solar collector uses a heat source from sunlight that enters the flat plate solar collector system and heats the water inside which will be used for heat sources in the evaporator. Evaporator itself to heat the working fluid and produce pressurized steam that will rotate the turbine, so it can produce electricity. The basic principle for calculating the efficiency of this collector is to compare the increase in temperature of the fluid flowing in the collector with the intensity of sunlight received by the collector. The following is a schematic diagram of the solar collector's flat-plate system : 


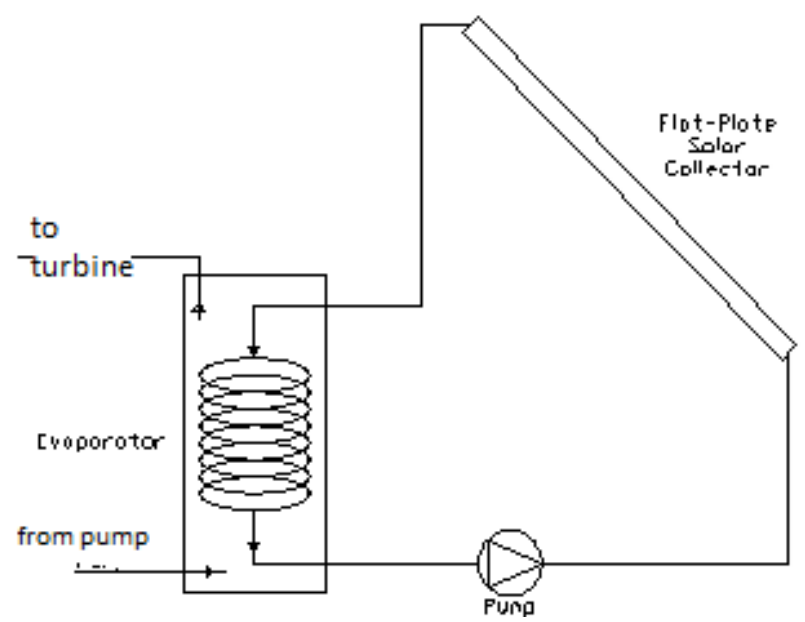

Figure. 4. Schematic Design of Flat-Plate Solar Collector System

In schematic figure 4, it known that there are several components needed. To get the calculation required the selection of components from the existing product catalog. The following components have been selected:

a. Flat-plate solar collector

\begin{tabular}{llll} 
Brand & $=$ & \multicolumn{2}{l}{ M4-200 } \\
High & $=$ & 2.06 & $\mathrm{~m}$ \\
Width & $=$ & 0.97 & $\mathrm{~m}$ \\
Thickness & $=$ & 0.09 & $\mathrm{~m}$
\end{tabular}

$\begin{array}{llll}\text { Maximum operating temperature } & = & 117,6 & { }^{\circ} \mathrm{C} \\ \text { Maximum operating pressure } & = & 1 & \mathrm{MP}\end{array}$

Efficiency Optical = $75.5 \%$

$\begin{array}{llll}\text { Volume } & = & 1.6 & \text { liter }\end{array}$

b. Pump

Brand

$\begin{array}{llll}\text { Power } & = & 1100 & \mathrm{~W} \\ \text { Head } & = & 21.5 & \mathrm{~m} \\ \text { Capacity } & = & 7.0 & \frac{m^{3}}{h} \\ & = & 1.94 & \end{array}$

Where the head needed for the system is $6.12 \frac{\mathrm{m}^{3}}{\mathrm{~h}}$

For flat-plate solar collector has an optical efficiency of $75.5 \%$ so that the volume can be charged at 1,208 liters. The system itself requires heating every 1.7 $\mathrm{kg}$ per second so that the required solar collector flat-plate is 2 pieces. After the modeling of the power plant system is made known. The following are the characteristics of the components of the Design of Organic Rankine Cycle (ORC) Power Plants by Using Flat-Plate Solar Collector.

TABLE 2.

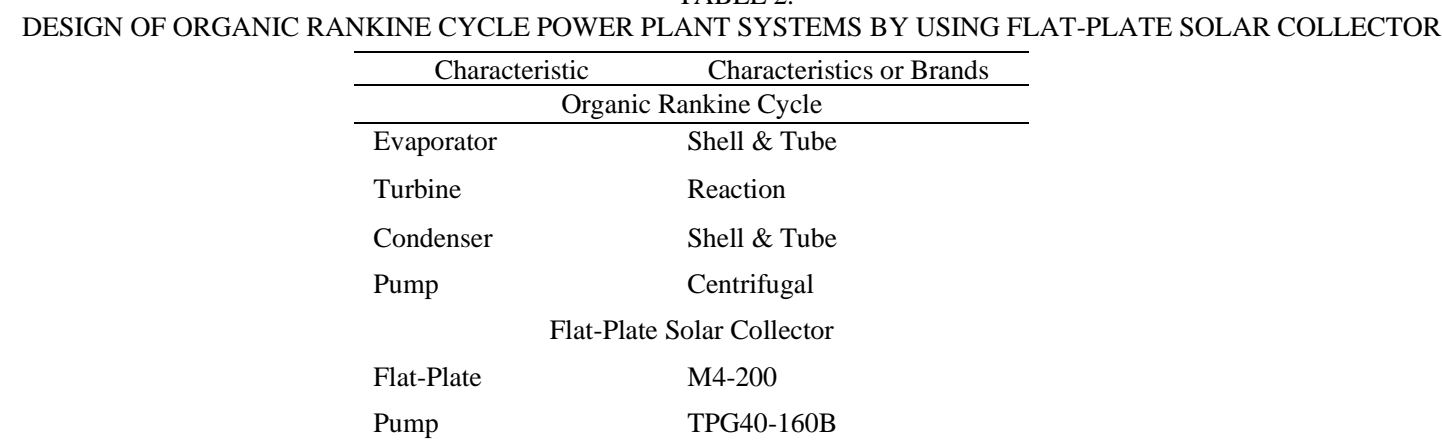

To obtain accurate data from the ORC model using Aspen Plus v10 modeling software, the parameter set of the study was designed with a mass flow rate of hot water from the solar collector of $1.7 \mathrm{~kg} / \mathrm{s}$ and cold water of $7 \mathrm{~kg} / \mathrm{s}$. The following parameter table will be given in the simulation: 
TABLE 3.

SIMULATION SET PARAMETERS

\begin{tabular}{|c|c|c|}
\hline Operational Parameters & Value & Unit \\
\hline \multicolumn{3}{|c|}{ Defined } \\
\hline Hot water temperature enters the evaporator & 92 & ${ }^{\circ} \mathrm{C}$ \\
\hline Cold water temperature enters the condenser & 27 & ${ }^{\circ} \mathrm{C}$ \\
\hline Hot water mass flow rate & 1.7 & $\mathrm{~kg} / \mathrm{s}$ \\
\hline Cold water mass flow rate & 7 & $\mathrm{~kg} / \mathrm{s}$ \\
\hline $\begin{array}{l}\text { The mass flow rate of the working fluid } \\
\text { R245FA }\end{array}$ & 1 & $\mathrm{Kg} / \mathrm{s}$ \\
\hline $\begin{array}{l}\text { Outlet Pressure of Flat-Plate Solar Collector } \\
\text { Pumps }\end{array}$ & 3.1 & bar \\
\hline Turbine Outlet Pressure & 2 & bar \\
\hline \multicolumn{3}{|c|}{ Variation } \\
\hline Pump Outlet Pressure & 3-6 & bar \\
\hline
\end{tabular}

The energy system from the ORC system design will be simulated using the Aspen Plus version 10. Figure 3. shows an example of displaying Aspen Plus v10 simulation results with R245FA working fluid on the ORC system design. In this study, variations will be made on the design of closed-cycle ORC systems with a singlestage model with variations in pump outlet pressure of 3 to 6 bars. The following are the results of the simulation of the parameters given:

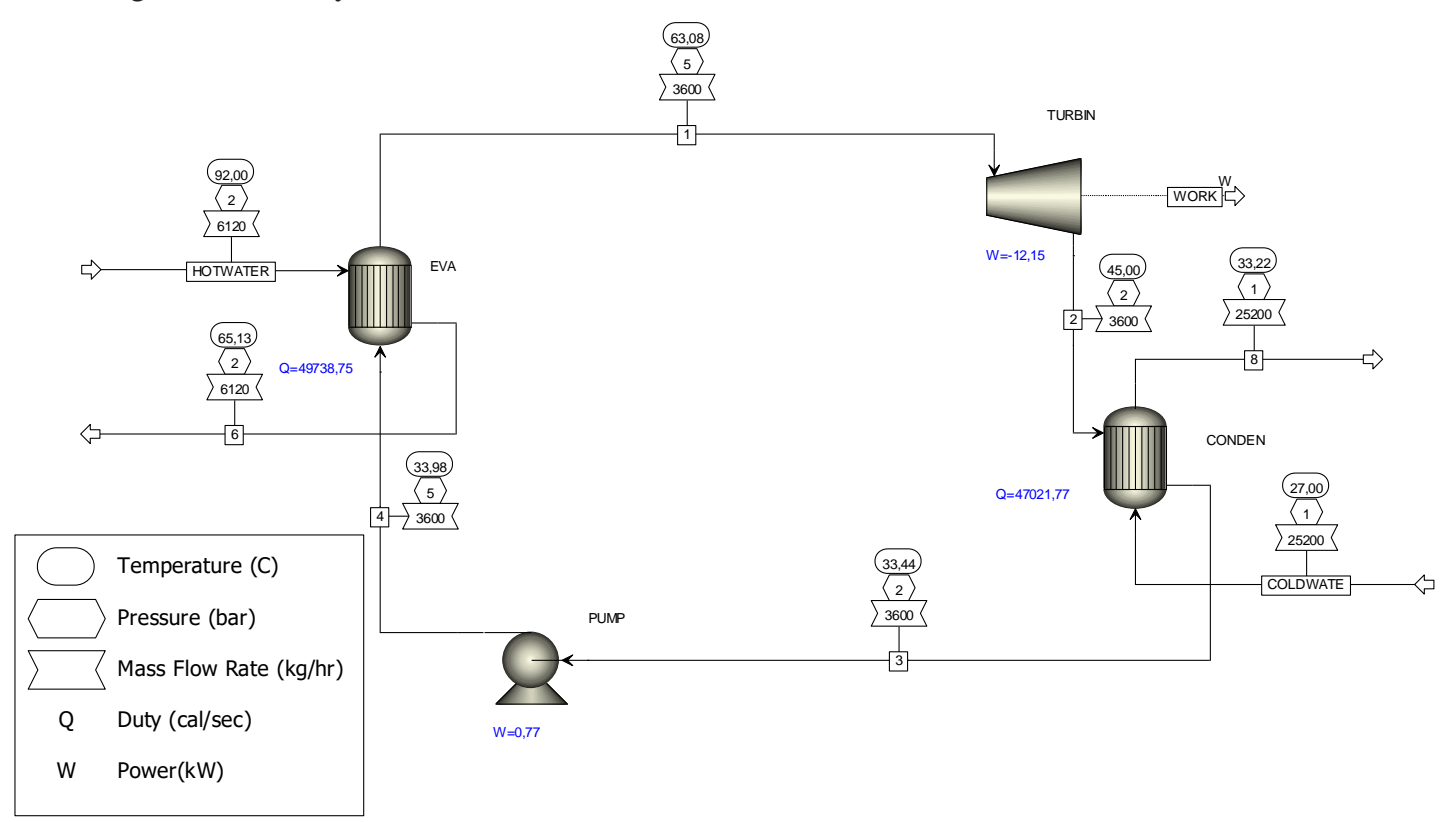

Figure. 5. ORC Design Simulation with 5 bar outlet pressure

In the simulation results shown in Figure 5 with a 5 bar outlet pressure, turbine power is generated at $12.15 \mathrm{~kW}$ and pump work is $0.77 \mathrm{~kW}$. In this simulation design, the results are close to the objectives of this study that is 10 $\mathrm{kW}$. These characteristics generated from the set parameters entered on each equipment that has designed. After entering the parameters, then running on the program, the program will calculate the input parameters to produce data such as figure 5. Below is the table of enthalpy wit manual calculation based on Aspen Plus v10:

TABLE 4.

ENTHALPY MANUAL CALCULATION IN EACH STATE

\begin{tabular}{|c|c|c|c|c|c|c|c|c|c|c|c|c|}
\hline \multirow{3}{*}{ Variation } & \multicolumn{12}{|c|}{ State } \\
\hline & \multicolumn{3}{|c|}{1} & \multicolumn{3}{|c|}{2} & \multicolumn{3}{|c|}{3} & \multicolumn{3}{|c|}{4} \\
\hline & $\begin{array}{c}\mathrm{T} \\
\left({ }^{\circ} \mathrm{C}\right)\end{array}$ & $\begin{array}{c}\mathrm{P} \\
\text { (bar) } \\
\end{array}$ & $\begin{array}{c}\mathrm{h} 1 \\
(\mathrm{~kJ} / \mathrm{Kg}) \\
\end{array}$ & $\begin{array}{c}\mathrm{T} \\
\left({ }^{\circ} \mathrm{C}\right) \\
\end{array}$ & $\begin{array}{c}\mathrm{P} \\
\text { (bar) }\end{array}$ & $\begin{array}{c}\mathrm{h} 2 \\
(\mathrm{~kJ} / \mathrm{Kg}) \\
\end{array}$ & $\begin{array}{c}\mathrm{T} \\
\left({ }^{\circ} \mathrm{C}\right) \\
\end{array}$ & $\begin{array}{c}\mathrm{P} \\
\text { (bar) }\end{array}$ & $\begin{array}{c}\mathrm{h} 3 \\
(\mathrm{~kJ} / \mathrm{Kg})\end{array}$ & $\begin{array}{c}\mathrm{T} \\
\left({ }^{\circ} \mathrm{C}\right) \\
\end{array}$ & $\begin{array}{c}\mathrm{P} \\
\text { (bar) } \\
\end{array}$ & $\begin{array}{c}\mathrm{h} 4 \\
(\mathrm{~kJ} / \mathrm{Kg})\end{array}$ \\
\hline 3 bar & 45.81 & 3 & -8744.34 & 38.2 & 2 & -8749.62 & 33.44 & 2 & -8940.3 & 33.62 & 3 & -8940.04 \\
\hline 4 bar & 55.28 & 4 & -8737.11 & 41.92 & 2 & -8746.23 & 33.44 & 2 & -8940.3 & 33.8 & 4 & -8939.78 \\
\hline 6 bar & 69.75 & 6 & -8726.38 & 47.61 & 2 & -8741.02 & 33.44 & 2 & -8940.3 & 34.16 & 6 & -8939.27 \\
\hline
\end{tabular}

In this study, the calculation with the input parameters is the same as the simulation obtained by turbine power, pump work, total work, and thermal efficiency. The results of the manual calculation found in table 5 and the simulation results tabulated in Table 6 as follows: 
TABLE 5.

MANUAL CALCULATION RESULT

\begin{tabular}{|c|c|c|c|c|}
\hline Variation & $\begin{array}{c}\text { 和urbine } \\
(\mathrm{kW})\end{array}$ & $\begin{array}{c}\dot{\text { Wpump }} \\
(\mathrm{kW})\end{array}$ & $\begin{array}{l}\dot{\text { Wnet }} \\
(\mathrm{kW})\end{array}$ & $\begin{array}{c}\text { Efficiency } \\
(\%)\end{array}$ \\
\hline 3 bar & 5,2833 & 0,2576 & 5,0257 & 2,54 \\
\hline 4 bar & 9,1196 & 0,5172 & 8,6024 & 4,24 \\
\hline 5 bar & 12,1484 & 0,773 & 11,3754 & 5,46 \\
\hline 6 bar & 14,6388 & 1,0304 & 13,6084 & 6,39 \\
\hline
\end{tabular}

TABLE 6.

SIMULATION CALCULATION RESULT

\begin{tabular}{ccccc}
\hline Variation & $\begin{array}{c}\dot{\text { Wturbine }}(\mathrm{kW}) \\
\text { 3 bar }\end{array}$ & $\begin{array}{c}\dot{\text { Wpump }} \\
(\mathrm{kW})\end{array}$ & $\begin{array}{c}\text { Wnet } \\
(\mathrm{kW})\end{array}$ & $\begin{array}{c}\text { Efficiency } \\
(\%)\end{array}$ \\
\hline 4 bar & 9.13 & 0.26 & 5.03 & 2.57 \\
\hline 5 bar & 12.15 & 0.51 & 8.62 & 4.25 \\
\hline 6 bar & 14.64 & 0.77 & 11.38 & 5.46 \\
\hline
\end{tabular}

The basic principle for calculating the efficiency of this collector is to compare the increase in temperature of the fluid flowing in the collector with the intensity of sunlight received by the collector. Here's the calculation on the solar collector's flat-plate system:

a. Energy calculations that are useful for collectors

$$
\begin{aligned}
Q_{u, a} & =\dot{\mathrm{m}} \cdot C_{p}\left(T_{o}-T_{i}\right) \\
Q_{u, a} & =1,7 \frac{\mathrm{kg}}{\mathrm{s}} \times 4,2 \frac{\mathrm{J}}{\mathrm{Kg} \cdot \mathrm{K}} \times(365-338.12) \mathrm{K} \\
Q_{u, a} & =191.92 \frac{\mathrm{J}}{\mathrm{S}} \\
Q_{u, a} & =191.92 \mathrm{~W}
\end{aligned}
$$

\section{Where :}

$$
\begin{aligned}
\dot{\mathrm{m}} & =1,7(\mathrm{Kg} / \mathrm{s}) \\
T_{i} & =65,12{ }^{\circ} \mathrm{C} \quad=338,12 \mathrm{~K} \\
T_{o} & =92{ }^{\circ} \mathrm{C} \quad=365 \mathrm{~K} \\
C_{p} & =4,2(\mathrm{~J} / \mathrm{Kg} . \mathrm{K}), \quad C_{p} \text { value is obtained by } \\
& \text { engineeringtoolbox.com from the properties of }
\end{aligned}
$$

water fluid $(\mathrm{H} 2 \mathrm{O})$ based on temperature $\left(T_{\text {film }}=\right.$ $\frac{T_{o}+T_{i}}{2}=\frac{365-338,12}{2}=351,56 \mathrm{~K}$ )

b. Calculation of actual efficiency

$$
\begin{aligned}
\eta_{a} & =\frac{Q_{u, a}}{A_{C} \cdot I_{T}} \\
\eta_{a} & =\frac{191 \cdot 92 W}{1,998 m^{2} \cdot 1000 \frac{W}{m^{2}}} \\
\eta_{a} & =0,096 \\
\eta_{a} & =9,6 \%
\end{aligned}
$$

Where:

$$
\begin{aligned}
A_{C} & =\text { height } \mathrm{x} \text { width flat-plate solar collector } \\
A_{C} & =2.06 \mathrm{~m} \times 0.97 \mathrm{~m} \\
A_{C} & =1,998 \mathrm{~m}^{2} \\
I_{T} & =1000 \frac{\mathrm{W}}{\mathrm{m}^{2}} \text { the intensity of the sun during the } \\
& \text { day) }
\end{aligned}
$$

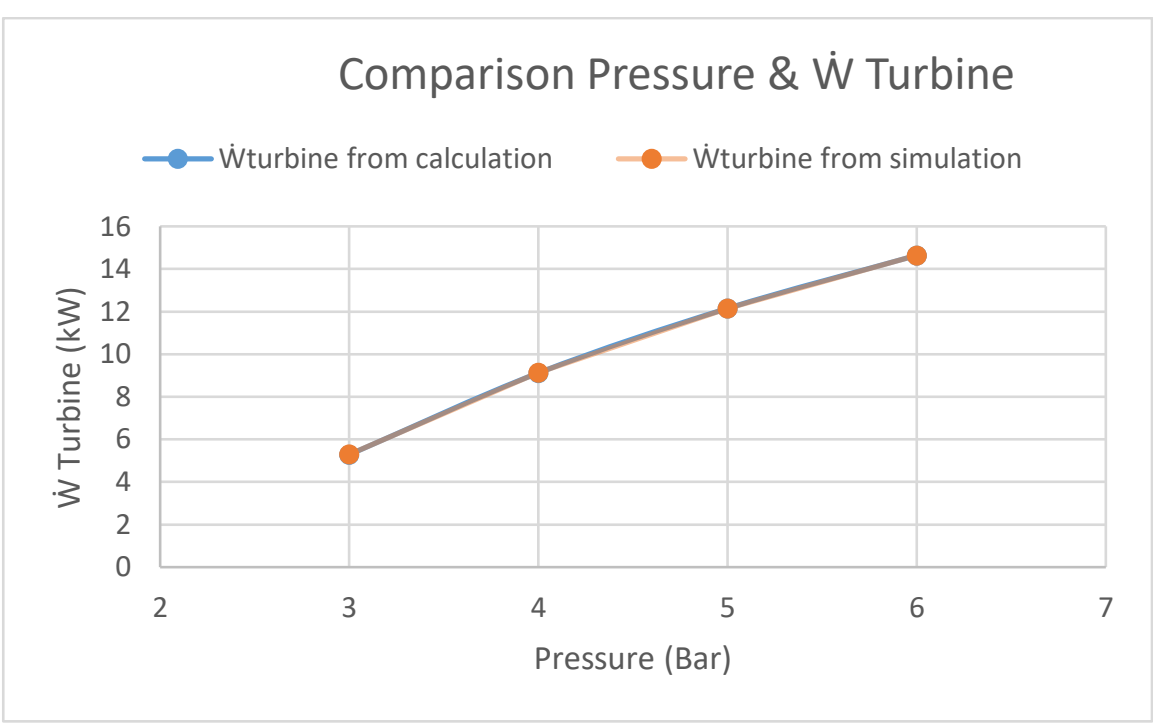

Figure. 6. Pump Outlet Pressure \& Turbine Power

Figure 6 is the ratio of pump outlet pressure to turbine power with 4 variations, namely a pressure of 3 to 6 bars from the results of calculations and simulations. Based on the graph above, it can be seen that the pump outlet pressure of 6 bar produces the highest turbine power and the pump outlet pressure of 3 turbine power bars produced lower. Where for the pump outlet of 6 bar produces power of $14.638 \mathrm{~kW}$ in manual calculations and $14.64 \mathrm{~kW}$ in the 
simulation, for pump outlets of 3 bars produces $5.583 \mathrm{~kW}$ of power in manual calculations and $5.29 \mathrm{~kW}$ in simulation. In the curve above, it can seem that the relationship of the pump outlet pressure to the turbine power is directly proportional to the mass of the same working fluid. The results of the simulation and calculation are by the theory; the greater the pressure produced by the pump, the greater the pressure received by the turbine blade. This causes the power generated by the turbine to increase.

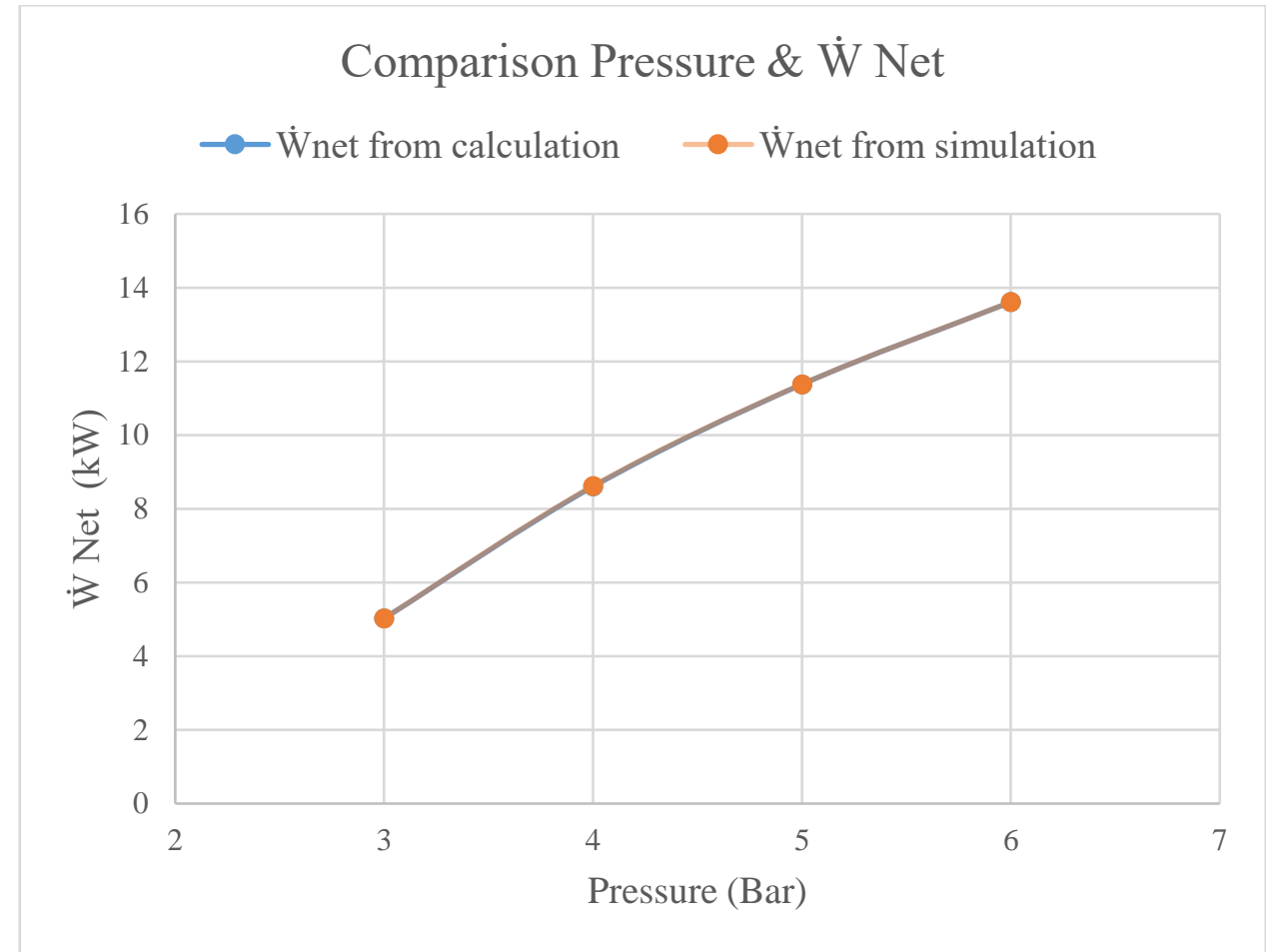

Figure. 7. Pump Outlet Pressure \& Total Work

Figure 7 is the pump outlet pressure ratio of total work with 4 variations, namely the pressure of 3 to 6 bars from the results of calculations and simulations. Based on the graph above, it can be seen that the pump outlet pressure of 6 bar produces the highest total of work and the pump outlet pressure of 3 total works produced is lower. Where for the pump outlet of 6 bar produces total work of $13.608 \mathrm{~kW}$ in manual calculations and $13.61 \mathrm{~kW}$ in the simulation, for pump outlets of 3 bars produces $5.025 \mathrm{~kW}$ of power in manual calculations and $5.03 \mathrm{~kW}$ in simulation. On the curve above, it can seem that the relationship of the pump outlet pressure with total work is directly proportional to the mass of the same working fluid. The results of the simulation and calculation are by the theory; the greater the pressure produced by the pump, the greater the increase in temperature at the evaporator received by the turbine blade. Even though the pump work that needed, the greater the total or total work remains, the bigger because the turbine power produced is greater.

\section{IV.CONCLUSION}

Some results that can be concluded from the analysis of the design of the ORC power generation system with flat plate solar collector using the aspen plus v10 software are as follows:

1. Simulation of the ORC generator system design with R245FA working fluid produces a power close to 10 $\mathrm{kW}$ at the pump outlet pressure of 5 bar with 11.38 $\mathrm{kW}$. The solar collector flat-plate system gets the energy that is useful for collectors of $191.92 \mathrm{~W}$ and efficiency of $9.8 \%$,
2. The design simulation of the ORC generator system with the working fluid R245FA produces the greatest power at the pump outlet pressure of 6 bar with Wnet of $13.61 \mathrm{~kW}$ and the smallest power is produced by the pump outlet pressure of $5.03 \mathrm{~kW}$. The resulting power increases with increasing outlet pressure from the pump. From these data, it can concluded that the amount of pressure produced by the pump can affect the speed of heat exchange in the evaporator and produce high-pressure steam with high pressure so that it can produce higher power.

\section{REFERENCES}

[1] Irawan, Riski. Manufacture and Testing of Flat-Plate Collectors (Steady-Plate Collectors) Steady Conditions Based on Standard En 12975: Mechanical Engineering Department, Faculty of Engineering, University of Lampung. 2015

[2] Wibowo, Teguh. Development of Binary Cycle at Organic Rankine Cycle (Orc) by Utilizing Solar Energy as a Heat Source: Mechanical Engineering Department, University of Indonesia. 2011

[3] Apriansyah, Angga. Design of Solar Power Plants with Organic Rankine Cycle (ORC) System. Pasundan University Mechanical Engineering. 2016

[4]Andinusa Rahmandhika, Sihana, Kutut Suryopratomo. Organic Rankine Cycle Analysis Using Solar Power With Vacuum Tube Type Collectors. Physics Department of Gadjah Mada University. 2015

[5] Arikundo, Fadly Rian, Mulfi Hazwi. Design of Flat Plate Type Solar Collector Prototype for Heat 
Producing in Dryers of Agricultural and Plantation Products. Mechanical Engineering Department of Gadjah Mada University. 2015

[6] Tahara, Haruo. Pumps and compressors, selection, use and maintenance. Instead of Sularso. PT Pradnya Paramita. Jakarta. 2006, pp. 5-60

[7] Putranto, Abyan Faris. Modification Design of Ocean Thermal Energy Conversion (OTEC) Generating System with Working Fluid Pre-Heater Using Ammonia (Nh3) and R-32 Refrigerants. Department of Shipping Systems Sepuluh Nopember Institute of Technology. 2018

[8] Pamungkas, A. H., \& Putra, A. B. K. Study of Refrigerant Flowrate Variations in Organic Rankine Cycle Systems with R-123 Working Fluid. Technical Journal of ITS, 2 (2), B273-B277. 2013

[9] Yamamoto, T., Furuhata, T., Arai, N., \& Mori, K. Design and testing of the organic Rankine cycle. Energy, 26 (3), 239-251. 2001

[10] Akbar, M. Wildam, \& Berkah Fajar TK. Condenser Design Type Shell and Tube Heat Exchanger for Organic Rankine Cycle System. Mechanical Engineering Department, Faculty of Engineering, Diponegoro University. 2015

[11] Astawa, Ketut, Si Putu Gede Gunawan Tista, I Wayan Hendra Saputra. Performance Analysis of Flat Plate Solar Collectors with Sand Heat Storage Media for Air Heaters. Mechanical Engineering Department of Udayana University. 2017
[12] Gowasmi and Kreith,. An Introduction to Solar Energy and Engineers. 1982, pp. 26-37

[13] Kreith, Frank, Principles of Heat Transfer, Erlangga, Jakarta. 1986, pp. 22-25

[14] AspenTech. Aspen Plus Version 8.8. Massachusetts, USA: AspenTech. 2018

[15] Fitri, S. P. Fluid Machine Teaching Materials. Surabaya, East Java, Indonesia. 2017 pp. 21-40

[16] John Wiley \& Sons, Inc . Computer Aided Thermodynamic Tables 3. United States of America. 1996, pp. 33-36

[17] Pamungkas, A. H., \& Putra, A. B. K. Study of Refrigerant Flowrate Variations in Organic Rankine Cycle Systems with R-123 Working Fluid. Technical Journal of ITS, 2 (2), B273-B277. 2013

[18] Moran, M. J. Fundamentals of Engineering Thermodynamics 5th Edition. Ohio: John Wiley \& Sons Ltd. 2016, pp.78-99

[19] Onny. Calculating Simple Rankine Cycle Efficiency. pp. Artikelteknologi.com. 2014

[20] H. Rosyid, R. Koestoer, N. Putra, Nasruddin, A.A. Mohamad, Yanuar, Sensitivity Analysis of Steam Powerplant-Binary Cycle. University of Indonesia. 2010

[21] Badr, O., O'Callaghan, P. W., \& Probert, S. D. Rankcycle systems for harnessing power from lowgrade energy sources. Applied Energy, 36 (4), 263-292. 1990 